\title{
Blended Learning dengan Macromedia Flash untuk Melatih Kemandirian Belajar Mahasiswa
}

\author{
Dina Octaria $^{1^{*}}$, Putri Fitriasari ${ }^{2}$, Novita Sari ${ }^{3}$ \\ ${ }^{1,2}$ Program Studi Pendidikan Matematika, Universitas PGRI Palembang \\ ${ }^{3}$ Program Studi Pendidikan Matematika, Universitas Sriwijaya \\ *dinaoktaria@gmail.com
}

\begin{abstract}
Abstrak
Kemandirian belajar di kalangan mahasiswa masih rendah. Ini terlihat dari mahasiswa kurang aktif dalam mencari sumber belajar dan hanya menunggu dari dosen, dari tugas pembuatan media pembelajaran yang diberikan mahasiswa masih banyak yang hanya menyalin dan mengedit saja. Untuk melatih kemandirian belajar, diperlukan suatu inovasi dalam pembelajaran, salah satunya menggunakan pembelajaran yang menggabungkan pembelajaran tatap muka dan virtual, yaitu blended learning. Penelitian ini bertujuan untuk melatih kemandirian belajar mahasiswa dalam membuat media pembelajaran berbasis Macromedia flash melalui blended learning. Metode penelitian yang digunakan yaitu metode deskriptif kuantitatif. Sampel dalam penelitian ini adalah mahasiswa program studi pendidikan matematika Universitas PGRI Palembang yang berjumlah 28 orang. Instrumen penelitian berupa angket kemandirian belajar mahasiswa yang diberikan sebelum dan sesudah pembelajaran. Data kuantitatif yang diperoleh dianalisis secara deskriptif. Hasil penelitian menunjukkan bahwa kemandirian belajar mahasiswa mengalami perubahan sebelum dan sesudah pembelajaran, dengan persentase perubahan terbesar terdapat pada indikator self efficacy (konsep diri), sedangkan persentase perubahan terkecil terdapat pada indikator mengevaluasi proses dan hasil belajar. Selanjutnya, upaya yang dapat dilakukan untuk melatih kemandirian belajar mahasiswa dengan blended learning yaitu menyediakan forum diskusi, memberikan tugas pada setiap materi agar mahasiswa mengetahui dengan jelas tujuan pembelajaran, melakukan pembahasan pada setiap tugas yang diberikan, dan tidak membatasi mahasiswa dalam mengakses sumber belajar.
\end{abstract}

Kata kunci: blended learning, kemandirian belajar, Macromedia flash

\begin{abstract}
Learning independence among students is still low. It can be seen from the students being less active in finding learning resources and only waiting from the lecturers, from the task of making learning media given by students there are still many who only copy and edit it. To practice learning independence, innovation is needed in learning, one of which uses learning that combines face-to-face and virtual learning, namely blended learning. This study aims to train the independence of student learning in making learning media based on Macromedia flash through blended learning. The research method used is quantitative descriptive method. The sample in this study were 28 students of the mathematics education program at the PGRI University of Palembang. The research instrument was a student learning independence questionnaire given before and after learning. The quantitative data obtained were analyzed descriptively. The results showed that student learning independence changes before and after learning, with the largest percentage change in the indicators of self-efficacy (self-concept), while the smallest percentage of changes in the indicators evaluating the learning process and results. Besides, the efforts that can be made to train the independence of student learning with blended learning are providing a discussion forum; giving assignments to each material so that students
\end{abstract}


know clearly the learning objectives; conducting discussions on each assignment given, and; do not limit students in access learning resources.

Keywords: blended learning, self-regulated learning, Macromedia flash

Received: November 2, 2019 / Accepted: January 11, 2020 / Published Online: January 31, 2020

\section{Pendahuluan}

Perkembangan revolusi industri yang terjadi di dunia, secara tidak langsung membawa perubahan terhadap perkembangan pendidikan di suatu negara. Sistem pendidikan dituntut untuk turut berbasis 4.0 yaitu sistem pendidikan yang lebih dinamis dan fleksibel. Menurut Aoun (2018) ada tiga literasi baru yang dikembangkan pada sistem pendidikan 4.0 yaitu 1) literasi data yang berkaitan dengan kemampuan membaca, menganalisis, dan memanfaatkan informasi big data dalam dunia digital, 2) literasi teknologi yang berkaitan dengan cara kerja mesin, aplikasi teknologi, dan 3) literasi manusia yang berkaitan dengan aspek humanities, komunikasi dan desain.

Ciri utama pendidikan 4.0 adalah pemanfaatan teknologi dalam proses pembelajaran, sehingga pembelajaran dapat dilakukan secara kontinyu tanpa harus selalu tatap muka di kelas. Dengan kata lain telah terjadi pergeseran pola pembelajaran dari ruang kelas ke di mana dan kapan saja, dari waktu siklus ke waktu nyata, dari fasilitas fisik ke fasilitas jaringan, dari kertas ke online, dan dari pelatihan ke penampilan (Rosenberg, 2001). Pembelajaran pada sistem pendidikan 4.0 berfokus pada: self-directed (proses pembelajaran terjadi karena kebutuhan yang dirasakan peserta didik), multi-sources (menggunakan berbagai sumber dan media pembelajaran), life-long learning (pembelajaran sepanjang hayat), pembelajaran menggunakan teknologi informasi, motivasi, sikap terhadap perubahan, adaptive, memiliki growth mindset bukan fixed mindset (Wibawa, 2018).

Perubahan pola pembelajaran yang terjadi saat ini terlihat dari sumber belajar yang sudah dapat diakses dari mana saja dan kapan saja. Pemanfaatan teknologi dalam sumber belajar dan konten belajar yang sudah banyak di youtube, aplikasi pembelajaran seperti edmodo dan schoology, serta konten bimbel online seperti ruangguru.com dan quiper.com. Perubahan pola pembelajaran berdampak pada tuntutan kualitas peserta didik dan pendidik.

Menurut Risdianto (2019), peran pendidik yang tidak dapat digantikan teknologi dalam interaksi pembelajaran, yaitu pendidik harus mampu membangun atmosphere yang dibutuhkan peserta didik secara psikologis. Kebutuhan psikologis peserta didik meliputi perasaan merasa bisa dalam pembelajaran, perasaan dihargai atas hasil belajar, merasa 
otonom dengan mendapatkan kebebasan dan kepercayaan, dan merasa dirinya bagian dari suatu kelompok. Pada proses pembelajaran, peserta didik yang otonom tidak akan selalu bergantung pada pendidik, dengan kata lain peserta didik memiliki kemandirian dalam belajar.

Kemandirian belajar merupakan kegiatan belajar yang dilakukan peserta didik tanpa bergantung pada bantuan dari pihak lain untuk mencapai tujuan pembelajaran (Suhendri, 2011; Rachmayani, 2014). Kemandirian belajar peserta didik perlu dikembangkan, hal ini dikarenakan peserta didik yang memiliki kemandirian belajar yang tinggi cenderung belajar lebih baik, mampu mengatur dan memantau belajarnya secara efektif, mengevaluasi, mengatur dan menghemat waktu dalam menyelesaikan tugasnya, serta memperoleh skor yang lebih tinggi dalam pelajaran sains (Hargis dalam Sumarmo, 2004), sehingga kemandirian belajar merupakan salah satu faktor yang dapat meningkatkan prestasi akademik peserta didik (Yanti \& Surya, 2017; Yamin, 2008; Abdullah \& Iannone, 2010).

Berdasarkan hasil pengamatan selama pembelajaran di kelas terhadap mahasiswa program studi pendidikan matematika yang mengambil mata kuliah ICT dalam pembelajaran matematika pada tahun ajaran 2017/2018, bahwa mahasiswa kurang aktif dalam mencari sumber belajar dan hanya menunggu dari pendidik, tidak semua mahasiswa terlibat aktif dalam proses pembelajaran, dari tugas pembuatan media pembelajaran yang diberikan mahasiswa masih banyak yang hanya menyalin dan mengedit saja. Melihat kondisi kemandirian belajar mahasiswa, maka diperlukan suatu inovasi dalam pembelajaran.

Salah satu solusi pembelajaran yang dapat melatih kemandirian belajar peserta didik dan sesuai dengan sistem pendidikan 4.0 adalah melalui pembelajaran terpadu atau secara blended learning. Menurut Syarif (2012) dan Skrypnyk, et al (2015), Blended learning adalah pembelajaran yang menggabungkan pembelajaran tatap muka dan virtual (e-learning). Manfaat Blended learning menurut Ronsen, dkk (Oktarina, Budiningsih \& Risdianto, 2018) yaitu 1) lebih efektif daripada hanya belajar tatap muka atau hanya belajar secara online, 2) dapat meningkatkan hasil belajar, 3) dapat menjadi cara yang tepat untuk memperpanjang waktu belajar, 4) dapat memungkinkan peserta didik memperoleh literasi digital dan keterampilan belajar online, 5) dapat menutupi pembelajaran yang tidak dapat dihadiri secara tatap muka, 6) membuat tugas menjadi lebih menarik dan fleksibel, 7) memungkinkan dilakukan pemantauan kemajuan peserta didik.

Beberapa peneliti telah melakukan penelitian terkait blended learning, penelitian tentang penerapan blended learning untuk meningkatkan kemandirian belajar peserta didik pada jenjang sekolah menengah atas dilakukan oleh Mayasari, dkk (2016); Farida dan Indah 
(2018). Sandi (2012) melakukan penelitian tentang penggunaan blended learning terhadap hasil belajar ditinjau dari kemandirian belajar pada jenjang sekolah menengah atas. Sedangkan Fitriasari dan Sari (2017) melakukan penelitian tentang penggunaan blended learning untuk melihat kemandirian belajar peserta didik pada jenjang perguruan tinggi. Selanjutnya penelitian ini meneliti tentang penggunaan blended learning untuk melatih kemandirian belajar peserta didik dalam menghasilkan media pembelajaran pada jenjang perguruan tinggi.

Beberapa peneliti sudah melakukan penelitian mengenai blended learning namun belum ada yang menggunakan Macromedia flash. Oleh karena itu, tujuan penelitian ini adalah untuk melatih kemandirian belajar mahasiswa dalam membuat media pembelajaran berbasis Macromedia flash melalui blended learning.

\section{Metode}

Metode penelitian yang digunakan dalam penelitian ini adalah deskriptif kuantitatif. Metode ini digunakan karena penelitian ini bertujuan mendeskripsikan secara sistematis, faktual, dan akurat mengenai fakta dan sifat populasi tertentu (Lehmann dalan Yusuf, 2017). Pada penelitian ini, subjek penelitian diberikan pembelajaran blended learning dimana pada pembelajaran online diakses melalui web schoology. Materi tentang Macromedia flash direkam menggunakan camtasia sehingga mahasiswa juga bisa mempelajarinya secara mandiri. Setelah mempelajari Macromedia flash dan mengamati media pembelajaran berbasis Macromedia flash yang telah ada, mahasiswa di pertemuan terakhir harus menghasilkan produk berupa media pembelajaran berbasis Macromedia flash. Kemampuan yang diukur dalam penelitian ini adalah kemandirian belajar mahasiswa.

Populasi dalam penelitian ini adalah mahasiswa Program Studi Pendidikan MatematikaUniversitas PGRI Palembang, sedangkan sampel adalah mahasiswa Program Studi Pendidikan Matematika yang mengikuti perkuliahan ICT dalam Pembelajaran Matematika pada semester genap, Februari - Mei tahun 2019 yang berjumlah 28 orang. Sampel dipilih dengan teknik purposive sampling, yaitu pemilihan sampel dengan tujuan tertentu.

Data dalam penelitian ini merupakan data kuantitatif yang dianalisis secara deskriptif. Teknik pengumpulan data dilakukan dengan angket kemandirian belajar. Angket diberikan untuk mengukur kemandirian belajar mahasiswa selama mengikuti pembelajaran blended learning,baik pembelajaran offline maupun pembelajaran online. Pembelajaran online bisa diakses melalui web schoology dan diberikan juga video tutorial menggunakan Macromedia 
flash. Angket kemandirian yang digunakan adalah modifikasi dari angket kemandirian belajar Fitriasari, dkk (2018).

\section{Hasil Penelitian}

Pelaksanaan pembelajaran blended learning pada penelitian ini dideskripsikan sebagai berikut:

1. Persiapan pembelajaran online

Untuk pembelajaran online menggunakan schoology, peneliti membuat kelas schoology dengan memberikan username dan password kepada mahasiswa agar dapat digunakan untuk login pada akun schoology. Peneliti menyediakan materi dalam bentuk Macromedia flash, membuat forum diskusi mahasiswa dan memberikan tugas untuk setiap materi, sedangkan untuk video tutorial diunggah di googledrive. Tampilan materi pada schoology dapat dilihat pada gambar 1 .

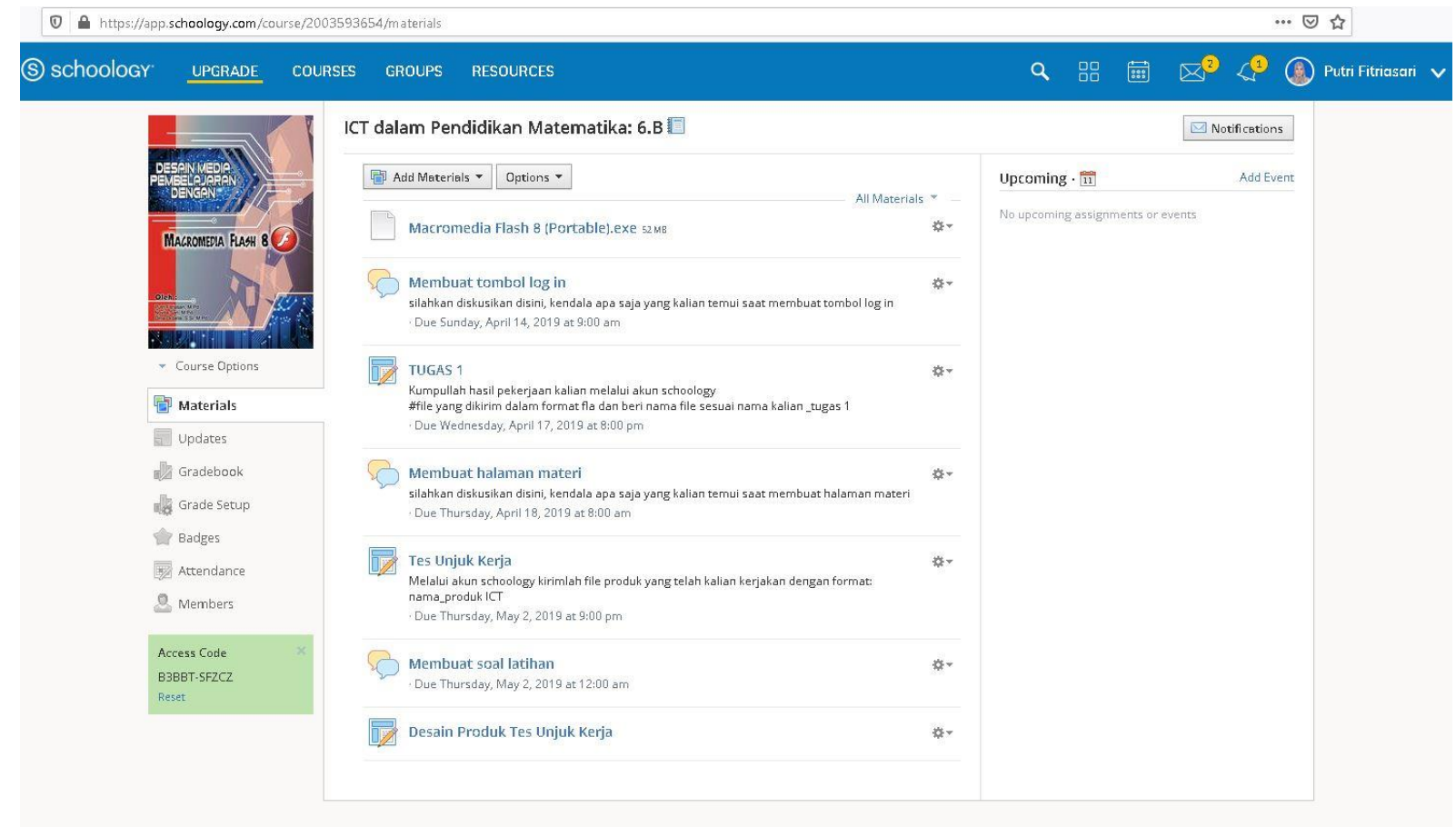

Gambar 1. Tampilan Materi pada Schoology

2. Pembelajaran tatap muka

Penelitian ini berlangsung sebanyak 3 kali pertemuan yang diikuti sebanyak 28 orang mahasiswa. Pertemuan pertama dilaksanakan pada tanggal 11 April 2019, pertemuan kedua dilaksanakan pada tanggal 18 April 2019, sedangkan pertemuan ketiga dilaksanakan pada tanggal 25 April 2019. Sebelum pembelajaran dimulai pada pertemuan pertama, mahasiswa diberikan angket kemandirian belajar terlebih dahulu. Materi pada pertemuan pertama yaitu pengenalan Macromedia flash 8, dan membuat halaman $\log$ in menggunakan Macromedia 
flash 8. Kegiatan pembelajaran pada pertemuan pertama dilaksanakan sesuai dengan rencana, namun pembelajaran berjalan lambat, dikarenakan mahasiswa belum pernah mempelajari Macromedia flash. Peneliti memberikan informasi bahwa pembelajaran online bisa diakses di akun schoology dengan username dan password masing-masing. Mahasiswa dapat melakukan diskusi dan mempelajari lagi materi yang sudah dipelajari dikelas dan dapat menonton video yang diunggah di google drive, pada masing-masing pertemuan mahasiswa mengerjakan tugas yang akan dikumpulkan pada akun schoology.

Pertemuan kedua, materi pembelajaran yaitu membuat halaman materi pada Macromedia flash. Kegiatan pembelajaran pada pertemuan kedua dilaksanakan sesuai dengan rencana, mahasiswa mulai terbiasa dengan pembelajaran menggunakan Macromedia flash, selain buku ajar yang digunakan sebagai sumber belajar untuk membuat halaman materi pada Macromedia flash, mahasiswa dapat melihat video tutorial, serta dapat berdiskusi dengan teman dan dosen melalui schoology.

Pertemuan ketiga, materi pembelajaran yaitu membuat soal pilihan ganda dengan Macromedia flash 8. Kegiatan pembelajaran pada pertemuan ketiga dilaksanakan sesuai dengan rencana, mahasiswa mulai menyelesaikan tugas yang telah mereka buat dari awal untuk dikumpulkan sebagai tugas mandiri pada schoology, setelah pembelajaran berakhir, mahasiswa diberikan angket kemandirian belajar. Proses pembelajaran mahasiswa dapat dilihat pada gambar 2 .
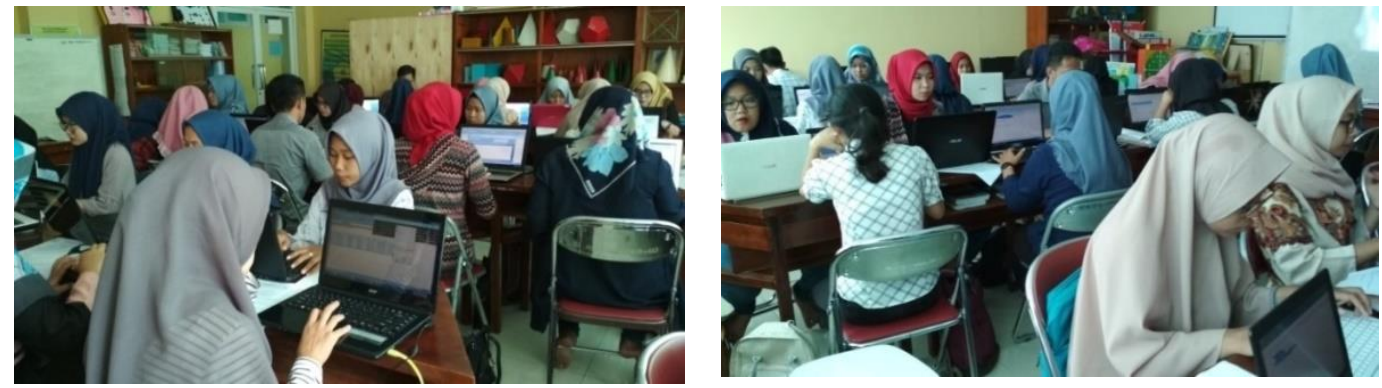

Gambar 2. Pelaksanaan pembelajaran tatap muka

\section{Pembelajaran online}

Mahasiswa login ke akun schoology menggunakan username dan password yang telah diberikan, mempelajari materi yang telah tersedia, saling berdiskusi mengenai pembelajaran dan tugas yang diberikan. Sedangkan, peneliti memantau aktivitas mahasiswa pada pembelajaran online, termasuk partisipasi mahasiswa dan keaktifan mahasiswa untuk berdiskusi dan pengumpulan tugas melalui webschoology. Tampilan diskusi pada schoology dapat dilihat pada gambar 3, sedangkan untuk pengumpulan tugas dapat dilihat pada gambar 4. 


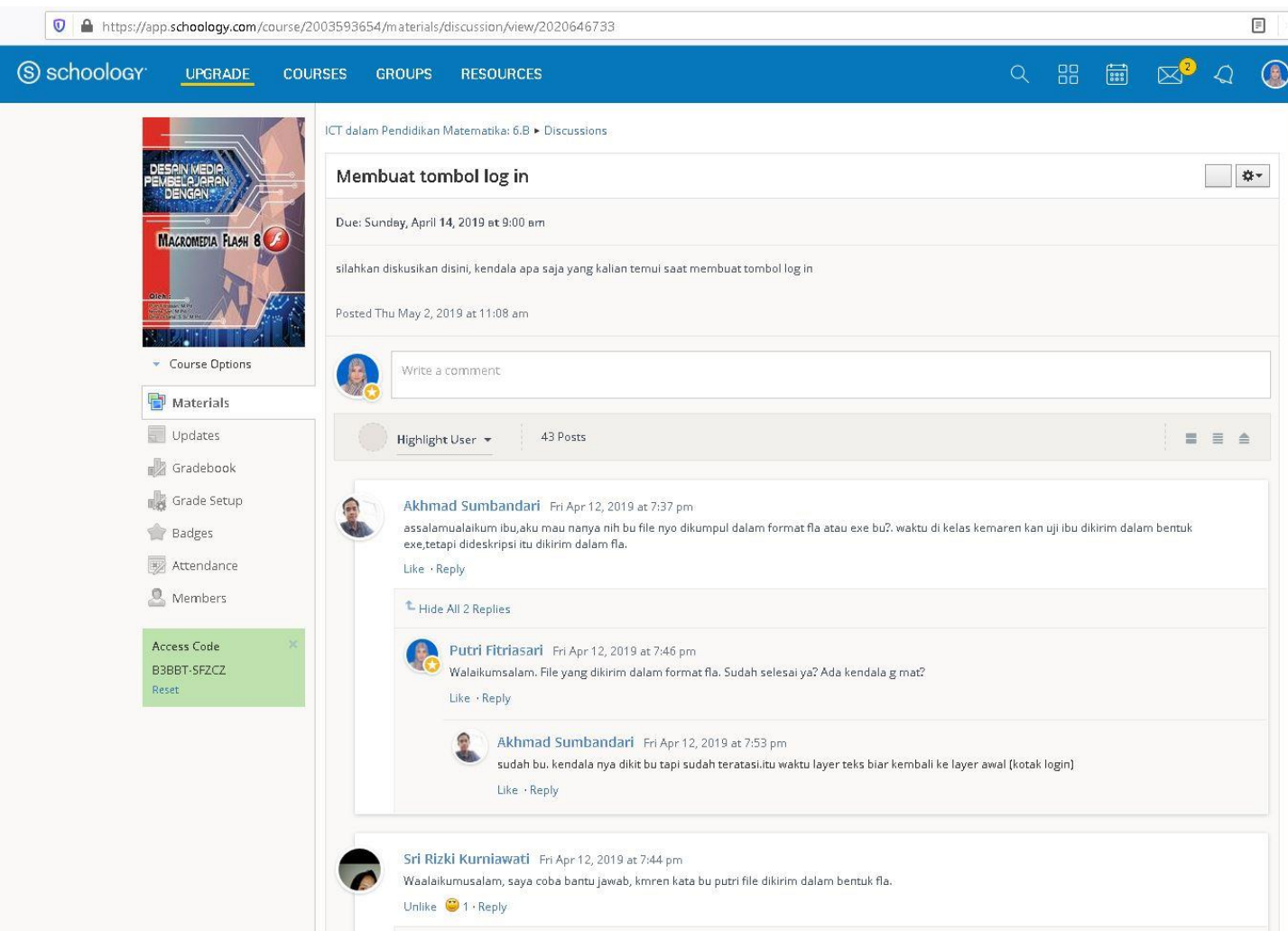

Gambar 3. Diskusi Mahasiswa pada schoology

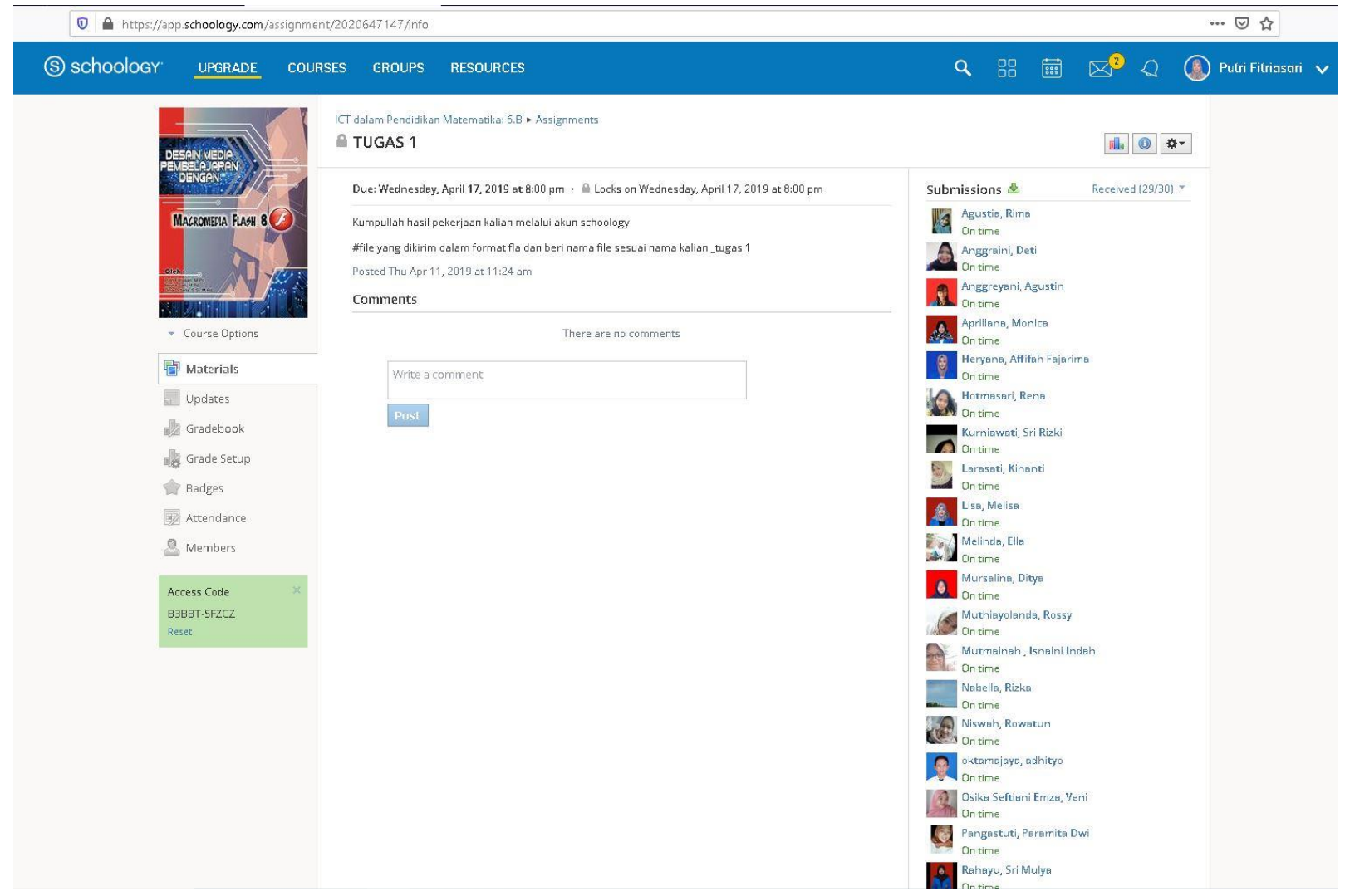

Gambar 4. Pengumpulan Tugas di Schoology

Produk hasil kerja mahasiswa sebelum pembelajaran dapat dilihat pada gambar 5, sedangkan 
produk hasil kerja mahasiswa setelah diterapkan model blended learning dapat dilihat pada gambar 6.
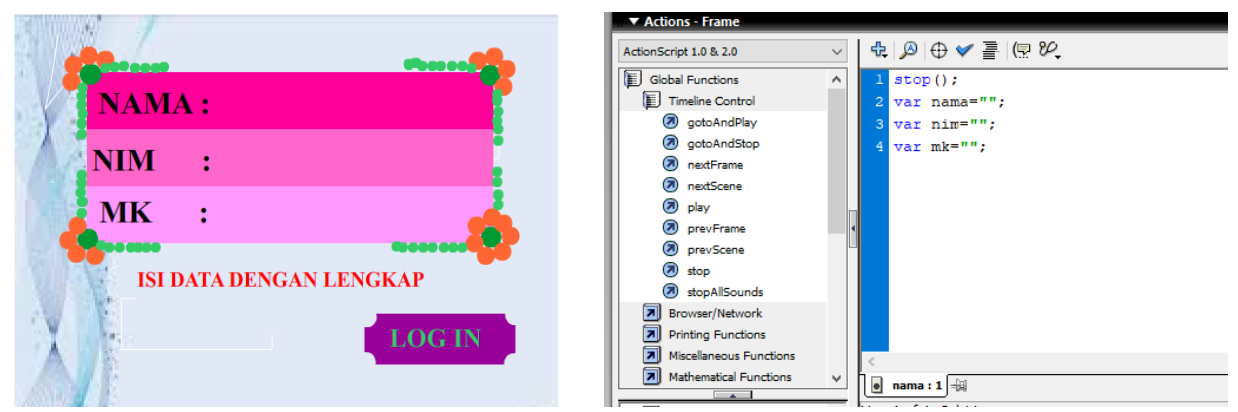

Gambar 5. Produk hasil kerja mahasiswa sebelum pembelajaran

Dari gambar 5, mahasiswa sudah dapat membuat tombol $\log$ in, namun program tidak dapat berjalan, hal ini dikarenakan terdapat kesalahan ketidakkonsistenan pada bahasa pemrograman yang digunakan. Setelah model blended learning diterapkan, mahasiswa mempunyai banyak waktu untuk belajar dan memahami materi, mahasiswa dapat menonton video pembelajaran, membaca buku, diskusi dan bertanya langsung ketika mahasiswa menghadapi kesulitan, sehingga diakhir pembelajaran produk hasil kerja mahasiswa sudah baik, seperti pada gambar 6 .
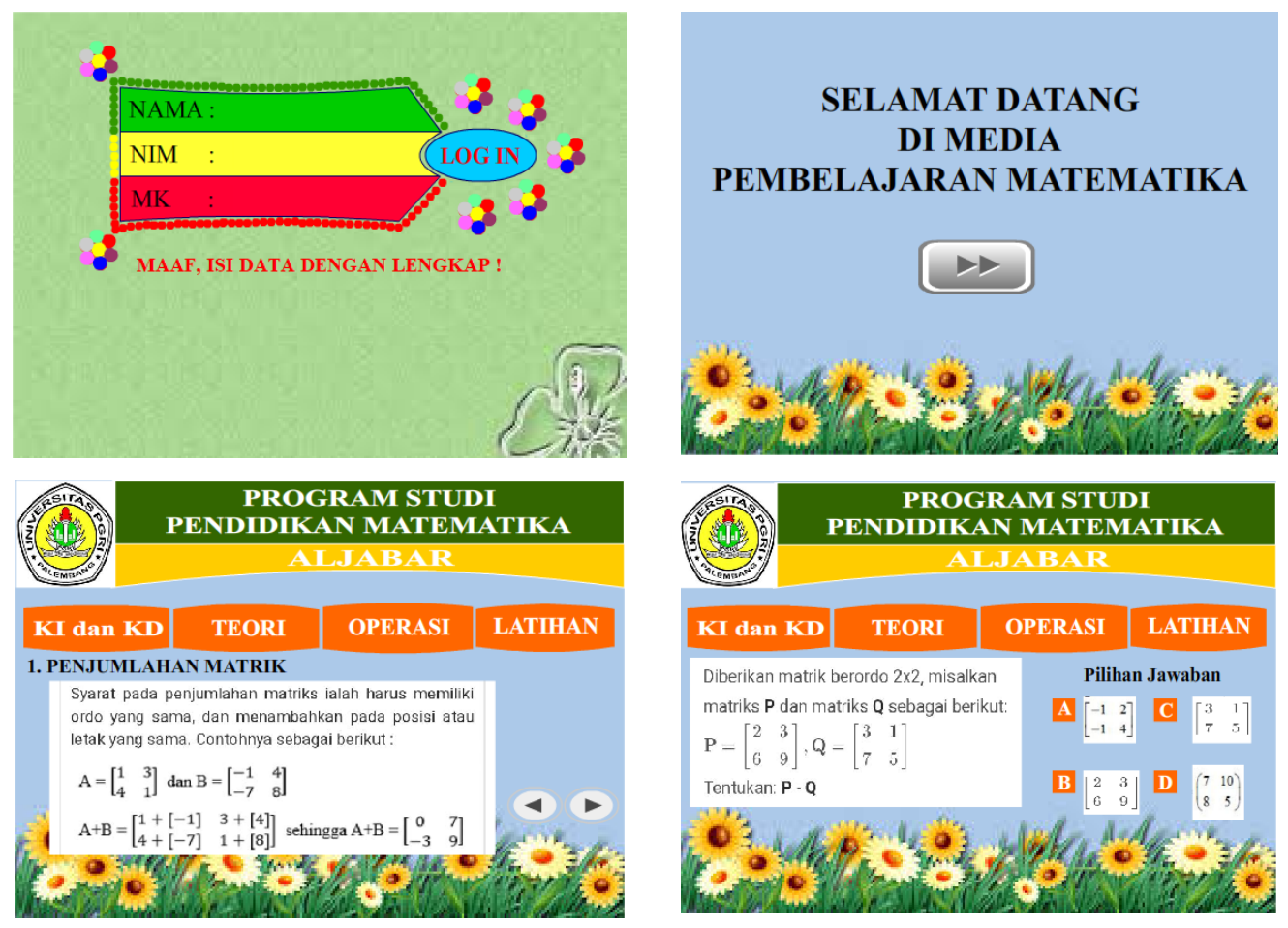

Gambar 6. Produk hasil kerja mahasiswa setelah pembelajaran 
Data kemandirian belajar mahasiswa dalam membuat media pembelajaran matematika berbasis Macromedia flash dengan blended learning dapat dilihat melalui angket kemandirian belajar. Angket kemandirian belajar diberikan sebanyak dua kali, yaitu sebelum dan sesudah pembelajaran, hal ini bertujuan untuk melihat apakah terdapat perbedaan kemandirian mahasiswa setelah membuat media pembelajaran berbasis Macromedia flash dengan blended learning. Angket kemandirian belajar mahasiswa dapat dilihat pada tabel 1.

Tabel 1. Deskriptif Statistik Kemandirian Belajar Mahasiswa

\begin{tabular}{|c|c|c|c|c|c|c|c|c|}
\hline \multirow{2}{*}{ No } & \multirow{2}{*}{ Indikator } & \multicolumn{3}{|c|}{ Sebelum Pembelajaran } & \multicolumn{3}{|c|}{ Setelah Pembelajaran } & \multirow{2}{*}{$\begin{array}{c}\% \\
\text { Kenai } \\
\text { kan }\end{array}$} \\
\hline & & $\bar{x}$ & $\%$ & Kategori & $\bar{x}$ & $\%$ & Kategori & \\
\hline 1 & $\begin{array}{l}\text { Inisiatif dan motivasi } \\
\text { belajar intrinsik }\end{array}$ & 2,73 & $\begin{array}{c}67,86 \\
\%\end{array}$ & Baik & 3,29 & $82,14 \%$ & $\begin{array}{l}\text { Sangat } \\
\text { Baik }\end{array}$ & $\begin{array}{c}14,28 \\
\%\end{array}$ \\
\hline 2 & $\begin{array}{l}\text { Mendiagnosa } \\
\text { kebutuhan belajar }\end{array}$ & 2,75 & $\begin{array}{c}68,75 \\
\%\end{array}$ & Baik & 3,23 & $80,80 \%$ & $\begin{array}{c}\text { Sangat } \\
\text { Baik }\end{array}$ & $\begin{array}{c}12,05 \\
\%\end{array}$ \\
\hline 3 & $\begin{array}{l}\text { Menetapkan tujuan/ } \\
\text { target belajar }\end{array}$ & 3,14 & $\begin{array}{c}78,57 \\
\% \\
\end{array}$ & Baik & 3,57 & $89,28 \%$ & $\begin{array}{l}\text { Sangat } \\
\text { Baik }\end{array}$ & $\begin{array}{c}10,71 \\
\%\end{array}$ \\
\hline 4 & $\begin{array}{l}\text { Memonitor, mengatur, } \\
\text { dan mengontrol belajar }\end{array}$ & 2,86 & $\begin{array}{c}71,42 \\
\%\end{array}$ & Baik & 3,17 & $79,17 \%$ & Baik & $7,75 \%$ \\
\hline 5 & $\begin{array}{l}\text { Memandang kesulitan } \\
\text { sebagai tantangan }\end{array}$ & 2,70 & $67,5 \%$ & Baik & 3,09 & $77,32 \%$ & Baik & $9,82 \%$ \\
\hline 6 & $\begin{array}{l}\text { Memanfaatkan dan } \\
\text { mencari sumber yang } \\
\text { relevan }\end{array}$ & 3,08 & $77 \%$ & Baik & 3,51 & $87,72 \%$ & $\begin{array}{l}\text { Sangat } \\
\text { Baik }\end{array}$ & $\begin{array}{c}10,72 \\
\%\end{array}$ \\
\hline 7 & $\begin{array}{l}\text { Memilih dan } \\
\text { menerapkan strategi } \\
\text { belajar }\end{array}$ & 2,92 & $\begin{array}{c}72,92 \\
\%\end{array}$ & Baik & 3,35 & $83,63 \%$ & $\begin{array}{l}\text { Sangat } \\
\text { Baik }\end{array}$ & $\begin{array}{c}10,71 \\
\%\end{array}$ \\
\hline 8 & $\begin{array}{l}\text { Mengevaluasi proses } \\
\text { dan hasil belajar }\end{array}$ & 3,06 & $\begin{array}{c}76,49 \\
\%\end{array}$ & Baik & 3,34 & $83,63 \%$ & $\begin{array}{l}\text { Sangat } \\
\text { Baik }\end{array}$ & $7,14 \%$ \\
\hline 9 & $\begin{array}{l}\text { Self efficacy (konsep } \\
\text { diri) }\end{array}$ & 2,89 & $\begin{array}{c}72,39 \\
\%\end{array}$ & Baik & 3,57 & $89,01 \%$ & $\begin{array}{l}\text { Sangat } \\
\text { Baik }\end{array}$ & $\begin{array}{c}16,62 \\
\%\end{array}$ \\
\hline
\end{tabular}

Berdasarkan tabel 1, dapat dilihat terjadi peningkatan untuk setiap indikator kemandirian belajar sebelum dan sesudah pembelajaran. Sebelum pembelajaran dimulai, kemandirian belajar mahasiswa berada pada kategori baik, namun setelah pembelajaran kemandirian belajar mahasiswa mengalami peningkatan sehingga berada pada kategori baik dan sangat baik. Sebelum pembelajaran, kemandirian mahasiswa paling besar berada pada indikator menetapkan tujuan/target belajar sebesar 78,57\%. Sedangkan, kemandirian belajar mahasiswa terkecil berada pada indikator memandang kesulitan sebagai tantangan sebesar 67,5\%. Setelah proses pembelajaran berlangsung kemandirian belajar mahasiswa terbesar tetap berada pada indikator menetapkan tujuan/target belajar sebesar 89,28\%, dan kemandirian belajar mahasiswa terkecil juga tetap berada pada indikator memandang kesulitan sebagai tantangan sebesar 77,32\%. Namun, untuk persentase kenaikan terbesar sebelum dan sesudah pembelajaran berada pada 
indikator self efficacy dengan kenaikan sebesar 16,62\%. Sedangkan untuk persentase kenaikan terkecil sebelum dan sesudah pembelajaran berada pada indikator mengevaluasi proses dan hasil belajar dengan kenaikan sebesar 7,14\%. Secara keseluruhan, kemandirian belajar mahasiswa melalui blended learning dikatakan baik.

\section{Pembahasan}

Sebelum pembelajaran menggunakan blended learning, indikator terbesar terdapat pada menetapkan tujuan/target belajar. Sedangkan, indikator terkecil terdapat pada memandang kesulitan sebagai tantangan, artinya mahasiswa sudah memiliki kesadaran dalam menetapkan tujuan/target belajar sebelum pembelajaran dimulai, namun belum memiliki kesadaran bahwa kesulitan dalam pembelajaran dapat dijadikan sebagai tantangan agar dapat mencapai hasil belajar yang baik.

Setelah pembelajaran blended learning, kemandirian belajar mahasiswa terbesar terdapat pada indikator menetapkan tujuan/target belajar, artinya dengan blended learning kesadaran mahasiswa dalam menetapkan tujuan/target belajar menjadi semakin baik. Hal ini dikarenakan mahasiswa telah mengetahui dengan jelas tujuan pembelajaran setiap pertemuan, sehingga tujuan akhir pembelajaran dapat lebih mudah dicapai. Sedangkan, indikator kemandirian belajar terkecil terdapat pada memandang kesulitan sebagai tantangan. Meskipun masih merupakan indikator terkecil, namun terdapat peningkatan yaitu sebesar 9,82\%. Artinya. Mahasiswa sudah memiliki kemampuan untuk mengubah kesulitan menjadi sebuah tantangan, sudah mengetahui kapan membutuhkan bantuan, dan kapan tidak membutuhkan bantuan orang lain dalam belajar. Hal ini sejalan dengan pendapat Ismaniati, dkk(2015) yang menyatakan bahwa seseorang yang memiliki kemandirian belajar sudah mengetahui pola pembelajarannya sendiri, sehingga dapat mengubah kesulitan menjadi tantangan.

Persentase kenaikan kemandirian belajar mahasiswa terbesar terdapat pada indikator self efficacy, yaitu sebesar 16,62\%. Hal ini dikarenakan pada blended learning, waktu belajar mahasiswa menjadi lebih lama, mahasiswa dapat berulang kali mempelajari buku ajar dan video tutorial, dan bisa saling diskusi jika mengalami kesulitan, sehingga mahasiswa dapat menguasai materi dengan lebih baik, dan kepercayaan diri menjadi meningkat. Hal ini sejalan dengan Marini, dkk (2017) yang menyatakan bahwa forum diskusi dapat melatih mahasiswa dalam berkomunikasi baik antar sesama juga dengan dosen, dan meningkatkan kepercayaan diri mahasiswa sehingga mahasiswa semangat dalam belajar.

Persentase kenaikan kemandirian belajar mahasiswa terkecil terdapat pada indikator mengevaluasi proses dan hasil belajar. Pada penelitian ini evaluasi proses dan hasil belajar 
mahasiswa hanya terlihat dari bahasa pemrograman yang digunakan dalam menghasilkan media pembelajaran matematika, jika bahasa pemrograman yang digunakan benar, maka media yang dihasilkan dapat dijalankan dengan baik, namun jika bahasa pemrograman yang digunakan salah, maka program tidak dapat berjalan. Sedangkan pada penelitian ini, mahasiswa hanya dituntut untuk teliti dalam menggunakan bahasa pemrograman, dikarenakan bahasa pemrograman dalam Macromedia flash sudah tersedia baik dalam buku ajar, maupun pada video tutorial.

Secara keseluruhan indikator kemandirian belajar mahasiswa mengalami peningkatan sebelum dan sesudah pembelajaran, sehingga dapat dikatakan bahwa blended learning dengan Macromedia flash dapat melatih kemandirian belajar mahasiswa dalam membuat media pembelajaran. Penelitian ini mendukung penelitian sebelumnya yang telah dilakukan oleh Poon (2013), Sari (2013), Ningsih, dkk (2017), dan Fitriasari, dkk (2018) yang menyatakan bahwa pembelajaran blended learning dapat memberikan hasil yang positif terhadap kemandirian belajar.

Pembelajaran blended learning dapat mengurangi jarak antara mahasiswa dan dosen, dapat meningkatkan interaksi diantara kedua belah pihak (Jusoff \& Khodabandelou, 2009), dapat meningkatkan akses informasi, kenyamanan, pengalaman belajar, dan fleksibilitas karena mahasiswa dan dosen dapat berpartisipasi dalam kelas secara online (Stein \& Graham, 2014), dapat meningkatkan penguasaan materi karena semakin sering mahasiswa mengakses materi semakin banyak materi yang diperoleh (Yanto \& Retnawati, 2018), serta meningkatkan pemahamaman menjadi lebih baik dengan penambahan visualisasi (Tan \& Erdogan, 2004; Yalin, 2002 dalam Cobanoglu \& Yurdaku, 2014). Di sisi lain, kemandirian belajar bersifat dinamis, artinya tidak luput dari perubahan dan kemandirian belajar berada pada ranah afektif, artinya pembentukan ranah afektif bersifat tidak langsung, dan membutuhkan waktu dalam proses pembelajaran (Gagne dalam Suherman, 2003). Sehingga pembelajaran blended learning belum memberikan kontribusi maksimal dalam kemandirian belajar. Hal ini sejalan dengan pendapat Sudiana, dkk (2017) yang menyatakan penyebab pembelajaran berbasis virtual class belum memberikan kontribusi yang baik terhadap pembelajaran, dikarenakan kemandirian belajar bersifat dinamis.

\section{Simpulan}

Kemandirian belajar mahasiswa mengalami perubahan sebelum dan sesudah pembelajaran. Tingkat kemandirian belajar mahasiswa, dengan persentase perubahan terbesar terdapat pada indikator self efficacy (konsep diri) sebesar 16,62\%, sedangkan persentase 
perubahan terkecil terdapat pada indikator mengevaluasi proses dan hasil belajar sebesar 7,14\%; (2) upaya yang dapat dilakukan untuk melatih kemandirian belajar mahasiswa dengan blended learning yaitu a)sediakan forum diskusi, b) berikan tugas pada setiap materi agar mahasiswa mengetahui dengan jelas tujuan pembelajaran, c) lakukan pembahasan pada setiap tugas yang diberikan, d) tidak membatasi mahasiswa dalam mengakses sumber belajar.

\section{Ucapan Terima Kasih}

Peneliti mengucapkan terima kasih kepada Menteri Riset, Teknologi, dan Pendidikan Tinggi yang telah memberikan sponsor penelitian ini melalui Hibah Penelitian Dosen Pemula untuk pendanaan tahun 2019 dan Universitas PGRI Palembang yang telah membantu terlaksananya penelitian ini.

\section{Referensi}

Abdullah, M. F. N. L., \& Iannone, P. (2010). Analysis of classroom interaction from the combined view of self-regulating strategies and discourse analysis: what can we do?. Proceedings of The British Congress for Mathematics Education, 30(1). 1-8.

Aoun, J. (2018). Robot-proof: higher education in the age of artificial intelligence. Journal of $\begin{array}{llll}\text { Education } & \text { for } & \text { Teaching, }\end{array}$ https://doi.org/10.1080/02607476.2018.1500792.

Cobanoglu, A., \& Yurdaku, B. (2014). The effect of blended learning on students' achievement, perceived cognitive flexibility levels and self-regulated learning skills. Journal of Education and Practice, 5(22), 176-197.

Farida, A. \& Indah, R. P. (2018). Penerapan blended learning untuk peningkatan kemandirian belajar dan critical thinking mahasiswa. Jurnal Derivat, 5(2), 19-27.

Fitriasari, P., \& Sari, N. (2017). Implementasi blended learning untuk meningkatkan kemandirian belajar mahasiswa pada mata kuliah metode numerik. Seminar Nasional Matematika dan Aplikasinya, Surabaya, Universitas Airlangga, 160-166. Diakses dari http://math.fst.unair.ac.id/wp-content/uploads/2017/10/24-PutriFitriasari_Pendidikan_.pdf.

Fitriasari, P., Tanzimah, \& Sari, N. (2018). Kemandirian belajar mahasiswa melalui blended learning pada mata kuliah metode numerik. Jurnal Elemen, 4(1). 1-8. https://doi.org/10.29408/jel.v4i1.439.

Ismaniati, Ch., Sungkono, \& Wahyuningsih, D. (2015). Model blended learning untuk meningkatkan kemandirian belajar dan daya tarik dalam perkuliahan. Jurnal Penelitian Ilmu Pendidikan, 8(2), 19-27. https://doi.org/10.21831/jpipfip.v8i2.8269.

Jusoff, K., \& Khodabandelou, R. (2009). Preliminary study on the role of social presence in blended learning environment in higher education. International Education Studies, 2(4), 79-83. https://doi.org/10.5539/ies.v2n4p79.

Marini, A., Rahman, C., \& Chandra, T. D. (2017). Peningkatan motivasi belajar siswa melalui penerapan pendekatan Realistic Mathematics Education (RME). Jurnal Pendidikan: Teori, Penelitian, dan Pengembangan. 2(4), 470-477.

Mayasari, F., Santoso, S., \& Octoria, D. (2016). Upaya meningkatkan kemandirian belajar siswa melalui penerapan blended learning berbantuan Quipper School. Jurnal Tata Arta UNS, 2(3), 148-161. 
Ningsih, Y. L., Misdalina, \& Marhamah. (2017). Peningkatan hasil belajar dan kemandirian belajar metode statistika melalui pembelajaran blended learning. Jurnal Pendidikan Matematika Al-Jabar, 8(2), 155-164. https://doi.org/10.24042/ajpm.v8i2.1633.

Oktarina, S. D., Budiningsih, A., \& Risdianto, E. (2018). Model blended learning berbasis moodle (1st ed). Jakarta: Halaman Moeka.

Poon, J. (2013). Blended learning: an institutional approach for enhancing students' learning experiences. MERLOT Journal of Online Learning and Teaching, 9(2), 271-289.

Rachmayani, D. (2014). Penerapan pembelajaran reciprocal teaching untuk meningkatkan kemampuan komunikasi matematis dan kemandirian belajar matematika siswa. Jurnal Pendidikan Unsika, 2(1), 13-23.

Risdianto, E. (2019). Analisis pendidikan indonesia di era revolusi industri 4.0. Bengkulu: Universitas Bengkulu. Diakses dari https://www.researchgate.net/profile/Eko_Risdianto/publication/332415017_ANALISI S_PENDIDIKAN_INDONESIA_DI_ERA_REVOLUSI_INDUSTRI_40/links/5cb4509 b4585156cd7993519/ANALISIS-PENDIDIKAN-INDONESIA-DI-ERA-REVOLUSIINDUSTRI-40.pdf.

Rosenberg, M. J. (2001). E-Learning: strategies for delivering knowledge in the digital age. New York: McGraw-Hill.

Sandi, G. (2012). Pengaruh blended learning terhadap hasil belajar kimia ditinjau dari kemandirian siswa. Jurnal Pendidikan dan Pengajaran, 45(3), 241-251.

Sari, A. R. (2013). Strategi blended learning untuk peningkatan kemandirian belajar dan kemampuan critical thinking mahasiswa di era digital. Jurnal Pendidikan Akuntansi Indonesia, 1(2), 32-43. https://doi.org/10.21831/jpai.v11i2.1689.

Skrypnyk, et al. (2015). The history and state of blended learning. Diakses dari https://www.researchgate.net/publication/313751703/download.

Stein, J., \& Graham, C. R. (2014). Essentials for blended learning: a standars-based guide. New York: Routledge. https://doi.org/10.4324/9780203075258.

Sudiana, R., Fatah, A., \& Khaerunnisa, E. (2017). Kemandirian belajar mahasiswa melalui pembelajaran berbasis virtual class. Jurnal Penelitian dan Pembelajaran Matematika, 10(1), 74-80. https://doi.org/10.30870/jppm.v10i1.1292.

Suhendri, H. (2011). Pengaruh kecerdasan matematis-logis dan kemandirian belajar terhadap hasil belajar matematika. Jurnal Ilmiah Pendidikan Matematika, 1(1), 29-39. https://doi.org/10.30998/formatif.v1i1.61.

Suherman, E. (2003). Evaluasi pembelajaran matematika. Bandung: Universitas Pendidikan Indonesia.

Sumarmo, U. (2004). Kemandirian belajar apa, mengapa dan bagaimana dikembangkan pada peserta didik. Makalah disajikan pada Seminar Pendidikan Matematika di Jurusan Pendidikan Matematika FMIPA Universitas Negeri Yogyakarta, tanggal 8 Juli 2014.

Syarif, I. (2012). Pengaruh model blended learning terhadap motivasi dan prestasi belajar siswa SMK. Jurnal Pendidikan Vokasi, 2(2), 234-249. https://doi.org/10.21831/jpv.v2i2.1034.

Wibawa, S. (2018). Pendidikan dalam era revolusi industri 4.0. Indonesia. Yogyakarta: UST Yogyakarta.

Yamin, M. (2008). Desain pembelajaran berbasis tingkat satuan pendidikan. Jakarta: Gaung Persada Press.

Yanti, S., \& Surya, E. (2017). Kemandirian belajar dalam memaksimalkan kualitas pembelajaran. Diakses dari https://www.researchgate.net/publication/321833928.

Yanto, B., \& Retnawati, H. (2018). Dapatkah model blended learning mempengaruhi kemandirian belajar matematika siswa? Jurnal Aksioma, 7(3), 324-333. https://doi.org/10.24127/ajpm.v7i3.1559. 
Yusuf, A. M. (2017). Metode penelitian kuantitatif, kualitatif, \& penelitian gabungan. Edisi cetakan keempat. Jakarta: Kencana. 